\title{
Isolasi Bakteri Endofit pada Tanaman Jeruk Keprok (Citrus reticulata) Madura dan Uji Potensi Antagonis dengan jamur Diplodia sp.
}

\section{Endophytic Bacteria Isolation in Keprok Orange Plants (Citrus reticulata)-Madura and Potensial Antagonistic Test to Fungus of Diplodia sp.}

\author{
Nurul Afiyatul Jannah ${ }^{1 *}$, Ahmad Syauqi ${ }^{2 * *}$, Hari Santoso ${ }^{3}$ \\ ${ }^{123}$ Jurusan Biologi Fakultas Matematika dan Ilmu Pengetahuan Alam Universitas Islam Malang, Indonesia
}

\begin{abstract}
ABSTRAK
Endofit dapat menghasilkan bioaktif metabolit dalam jumlah banyak, yang terlibat didalam hubungan antara endofit dan inang. Diantara bakteri potensial antagonis yang dapat digunakan sebagai pengendali hayati adalah bakteri endofit yaitu bakteri yang hidup didalam jaringan tanaman dan dapat berpindah antar jaringan. Salah satu alternatif pengendalian penyakit pada tanaman jeruk adalah menggunaan agen hayati yang bersifat antagonis terhadap penyebab penyakit. Eksplorasi agen hayati dilakukan dengan mengisolasi bakteri endofit daun tanaman jeruk keprok varietas Madura. Tujuan penelitian adalah menentukan indeks keragaman mikroorganisme bakteri endofit daun jeruk keprok varietas Madura dan mempelajari sifat Antagonis koloni bakteri Endofit kepada jamur Diplodia sp. Penelitian menggunakan metode deskrptif dan eksperimental dengan dengan mempertimbangkan tujuan penelitian. Pengamatan dilakukan dengan mengunakan media PCA (Plate Count Agar), NA (Nutrient Agar), dan MCA (Mac Conkey Agar). Indeks keragaman mikroorganisme bakteri endofit yang diisolasi dari daun jeruk keprok varietas Madura yaitu ada 9 macam koloni bakteri yang didapat E1 warna putih susu, E2 putih susu, E3 putih susu, E4 putih susu, E5 putih, E6 putih, E7 putih, E8 Kuning dan E9 putih bening. Setelah dilakukannya uji antagonis sifat dari koloni bakteri dengan jamur diplodia sp ada empat macam koloni bakteri endofit yang bersifat antagonis yaitu E3 persentase (47,5\%), E4 persentase (35,31\%), E6 persentase (35\%), terakhir yaitu dari E9 persentase $(63,43 \%)$.
\end{abstract}

Kata kunci: Bakteri Endofit, daun jeruk, jamur diplodia.

\section{ABSTRACT}

Endophytes can produce large quantities of bioactive metabolites, which are involved in the relationship between endophytes and hosts. Among the potential antagonistic bacteria that can be used as biological controllers are endophytic bacteria, namely bacteria that live in plant tissues and can move between tissues. One alternative to controlling diseases in citrus plants is to use biological agents that are antagonistic to the cause of the disease. Exploration of biological agents was carried out by isolating endophytic bacteria leaves of Madura varieties. The aim of researh was to determine the diversity index of endophytic bacteria from the leaves of Madura variety and to know the antagonistic colonies of endophytic bacteria toward Diplodia sp. The study used descriptive and experimental methods with taking into account the research objectives. Observations were carried out using PCA (Plate Count Agar) media, NA (Nutrient Agar), and MCA (Mac Conkey Agar). Diversity index of endophytic bacterial microorganisms isolated from the leaves of Madura varieties, namely 9 types of bacterial colonies obtained E1 milky white, E2 milky white, E3 milky white, E4 milky white, E5 white, E6 white, E6 white, E7 white, E8 Yellow and E9 clear white. After the antagonistic test of the nature of the bacterial colonies with the diplodia fungus sp, there were four types of antagonistic endophytic bacteria colonies namely E3 percentage (47.5\%), E4 percentage (35.31\%), E6 percentage (35\%), lastly E9 percentage (63, 43\%).

Keywords: Endophytic bacteria, orange leaves, diplodia fungus.

\footnotetext{
${ }^{*}$ Nurul Afiyatul Jannah, Jurusan Biologi FMIPAUNISMA, J1. Mt. Haryono 193, Malang 65144, 081357168772 and E-mail: nurulafiyatuljannah@gmail.com

${ }^{* *}$ Ir. Ahmad Syauqi, M. Si, Jurusan Biologi FMIPA UNISMA. Jl. Mt. Haryono 193, Malang 65144, 08986307836 and E-mail: syauqi.fmipa@unisma.ac.id
}

Diterima Tanggal 30 Januari 2019 dan Publikasi Tanggal 25 Agustus 2019 


\section{Pendahuluan}

Beberapa tahun terakhir ini penggalian sumber daya mikroba yang terdapat di dalam jaringan tanaman mulai banyak mendapat perhatian. Dikatakan oleh Petrini (1991) [1] bahwa bakteri endofitik yang hidup di dalam tanaman tidak merugikan inangnya. Telah diketahui pula bahwa hubungan antara mikro endofitik dengan tanaman adalah karena kontribusi senyawa kimia yang dihasilkan oleh mikroba yang memiliki berbagai jenis bioaktif (Melliawati.R, 2006) [2]. Pengendalian dengan memanfaatkan teknologi hayati yang lebih efektif dan ramah lingkungan. Di antara bakteri potensial antagonis yang dapat digunakan sebagai pengendali hayati adalah bakteri endofit yaitu bakteri yang hidup didalam jaringan tanaman dan dapat berpindah antar jaringan. Menurut Hallman (1997) [3] bakteri endofit dapat berpengaruh pada kesehatan tanaman dalam hal: antagonisme langsung, menginduksi ketahanan sistemik dan meningkatkan toleransi tanaman terhadap tekanan lingkungan. Manfaat lain dari aplikasi bakteri ini, yaitu tidak akan meninggalkan residu kimia dan tidak menyebabkan resistensi.

Jeruk keprok (Citrus nobilis Lour.) merupakan salah satu spesies dari sekian banyak spesies jeruk yang sudah dikenal dan dibudidayakan di Indonesia. Ketahanan tanaman jeruk fusiprotoplas telah diuji terhadap infeksi jamur Botriodiplodia theobromae, dikelompokkan ke dalam tiga kategori yaitu tahan, moderat, dan rentan (Puspita, dkk 2013) [4]. Ketahanan terhadap serangan patogen diduga disebabkan karena metabolit sekunder yang dikeluarkan oleh tanaman yang berasosiasi dengan jamur endofit (Adler et al., 2001; Zhao et al., 2010; Erdogan et al., 2012; Maknickiene et al., 2013)) [5]. Endofit dapat menghasilkan bioaktif metabolit dalam jumlah banyak, yang terlibat di dalam hubungan antara endofit dan inang, serta endofit dapat berpotensi untuk menghasilkan produk alami yang digunakan dalam bidang industri farmasi maupun pertanian (Puspita, dkk 2013) [6]. Salah satu penyakit tanaman jeruk yaitu penyakit blendok yang disebabkan oleh jamur Diplodia sp. yang menyerang bagian batang dan cabang. Blendok berupa cairan atau gom berwarna kuning emas yang keluar dari batang dan cabang (Soelarso, 1996) [7]. Dan pada jamur Diplodia sp. Sering menyerang terhadap perumbuhan tanaman jeruk Keprok Madura.

Tujuan penelitian yaitu untuk mengetahui indeks keanekaragaman koloni baktei endofit yang di isolasi dari daun jeruk keprok Madura dan untuk mengetahui sifat antagonis koloni bakteri endofit dari daun jeruk keprok Madura dengan jamur Diplodia sp.

\section{Material dan Metode}

\section{Bahan dan Alat}

Bahan yang digunakan pada penelitian ini adalah, Plate Count Agar (PCA), Mac Conkey Agar (MCA), Nutrient Agar (NA), isolat jamur diplodia yang di ambil dari laboratorium Balai penelitian tanaman jeruk dan buah subtropika (Balitjestro) Batu, daun jeruk keprok bervarietas Madura yang didapat dari Kebun Percobaan Kliran yang merupakan satu bagian dari Balai penelitian tanaman jeruk dan buah subtropika (Balitjestro) Batu, Aquades, Alkohol 70\%, Phospat Buffered Saline (pbs) pepton, Safranin, kristal violet, iodin, etanol 95\%.

Alat yang digunakan dalam penelitian ini adalah, kaca preparat, cawan petri, penggaris, spidol, buku, bolpoint, kamera hp, autoclave, tissue, erlanmayer, kapas, wepring, kertas kayu, oven, timbangan analitik, tabung reaksi, vortex/sentrifuge, dan jarum oase, mikroskop, incubator, Bunsen, pipiet tetes, pipet ukur, kompor gas, tabung LPG, LAF (Laminar Air Flow), koloni counter, hot plate, magnetic stirrer, spatula, gelas ukur.

\section{Metode}

Penelitian ini menggunakan metode deskriptif eksperimental untuk mengetahui indeks keanekaragaman mikroorganisme bakteri endofit daun jeruk keprok varietas Madura dan uji 
Antagonis koloni bakteri Endofit kepada jamur patogen Diplodia sp., Pengambilan sampel dilakukan secara sengaja tersedia di perkebunan percobaan kliran yang merupakan satu bagian dari Balai penelitian tanaman jeruk dan buah subtropika (Balitjestro) Batu, tempat sesusai dengan konteks yang diinginkan peneliti. Ulangan dilakukan hanya pada koloni yang di dapat pada waktu isolasi dan pada uji antagonis.

\section{Cara Kerja}

Isolasi bakteri dimulai dari pengambilan sampel yaitu daun jeruk sehat tidak berbintik-bintik dan bernoda-noda yang diambil yaitu yang sehat. Sampel daun jeruk dimulai dari pembersian menggunakan tissue, daun jeruk di rendam kedalam Alkohol 70\% selama \pm 3 menit. Selanjutnya setelah direndam dipotong kecil-kecil dan di siapkan 8 tabung reaksi dan diisi phospat buffered saline (PBS) Pepton sebagai pelarut sebanyak $9 \mathrm{ml}$. bagian daun tersebut di masukkan dan ditutup menggunakan aluminium voil, dan divortex \pm 3 menit, di tunggu hingga mengendap. Setelah itu suspensi diambil $1 \mathrm{ml}$ untuk diencerkan. Masing-masing tabung diberi label $10^{-1}, 10^{-2}, 10^{-3}, 10^{-4}, 10^{-5}$, dan $10^{-6}$. Diambil $1 \mathrm{~mL}$ sampel dan diencerkan pada tabung reaksi $10^{-1}$ dan pengenceran terus dilakukan sampai pada tabung reaksi $10^{-6}$. Diambil $1 \mathrm{~mL}$ dari tabung reaksi $10^{-5}$ dan $10^{-6}$ dengan pipet tetes steril secara aseptis dan ditanam ke dalam media PCA, NA dan MCA yang telah disiapkan. Cawan diputar seperti angka 8 (delapan) tanpa mengangkat cawan tersebut. Diinkubasi pada suhu $31^{\circ} \mathrm{C}$ selama 24-48 jam (Syauqi, 2017) [8].

Macam koloni yang tumbuh pada media penangkapan mikroba diamati dengan mikroskop meliputi: bentuk, warna. Dibuat tabel data pengamatan macam koloni, populasi dan jenis gram bakteri tanah kemudian dilihat jumlah spesiesnya dan dihitung keseluruhan jumlah individu. Dibuat Tabel Data Pengamatan Jumlah Spesies dan Individu Komunitas Bakteri Tanah Kemudian dihitung indeks keragaman koloni bakteri tersebut. Sebelum dihitung indeks keragamannya, dengan Rumus Indeks Keragaman :

$$
\mathbf{H}^{\prime}=-\sum \text { pi In pi }
$$

Dimana:

$$
\begin{array}{ll}
\mathrm{H}^{\prime} & \text { : Indeks Keragaman } \\
\mathrm{Pi} & \text { : ni/N (nilai perbandingan jumlah dan total individu spesies ke-i) } \\
\mathrm{ni} & \text { : jumlah individu macam spesies ke-i } \\
\mathrm{N} & \text { : jumlah total individu semua spesies }
\end{array}
$$

Pemurnian bakteri yang akan digunakan sebagai uji antagonis diambil dari kultur campuran yang telah dihitung indeks keragamannya, Disiapkan cawan petri yang berisi kultur campuran dan tabung reaksi yang telah berisi media PCA steril sebanyak jumlah macam koloninya, Disiapkan jarum oase, bunsen, korek api, alkohol 70\% dalam gelas bekker, Dinyalakan bunsen dan dilakukan seleksi koloni bakteri dengan jarum oase digesekkan pada koloni yang dipilih dan dilakukan teknik streak ke media PCA pada tabung reaksi, Setiap akan mengisolasi koloni dilakukan pembakaran jarum oase hingga membara pada Bunsen, Ketika jarum tidak digunakan maka jarum dicelupkan ke dalam alkohol pada gelas bekker, Diberi label pada tabung reaksi tersebut, Kemudian tabung ditutup kembali dengan menggunakan kapas, dibungkus dengan kertas sampul dan diikat dengan benang, Dimasukkan tabung reaksi yang berisi kultur murni kedalam inkubator pada suhu $30^{\circ} \mathrm{C}$, Dibiarkan selama 24 jam dan diamati koloni tiap tabung reaksi. 


\section{Hasil dan Diskusi}

\section{Hasil Penelitian dan Pembahasan}

Diagram dari indeks keanekaragaman bakteri endofit jeruk yang di dapat pada taaman jeruk keprok Madura pada Gambar 1.

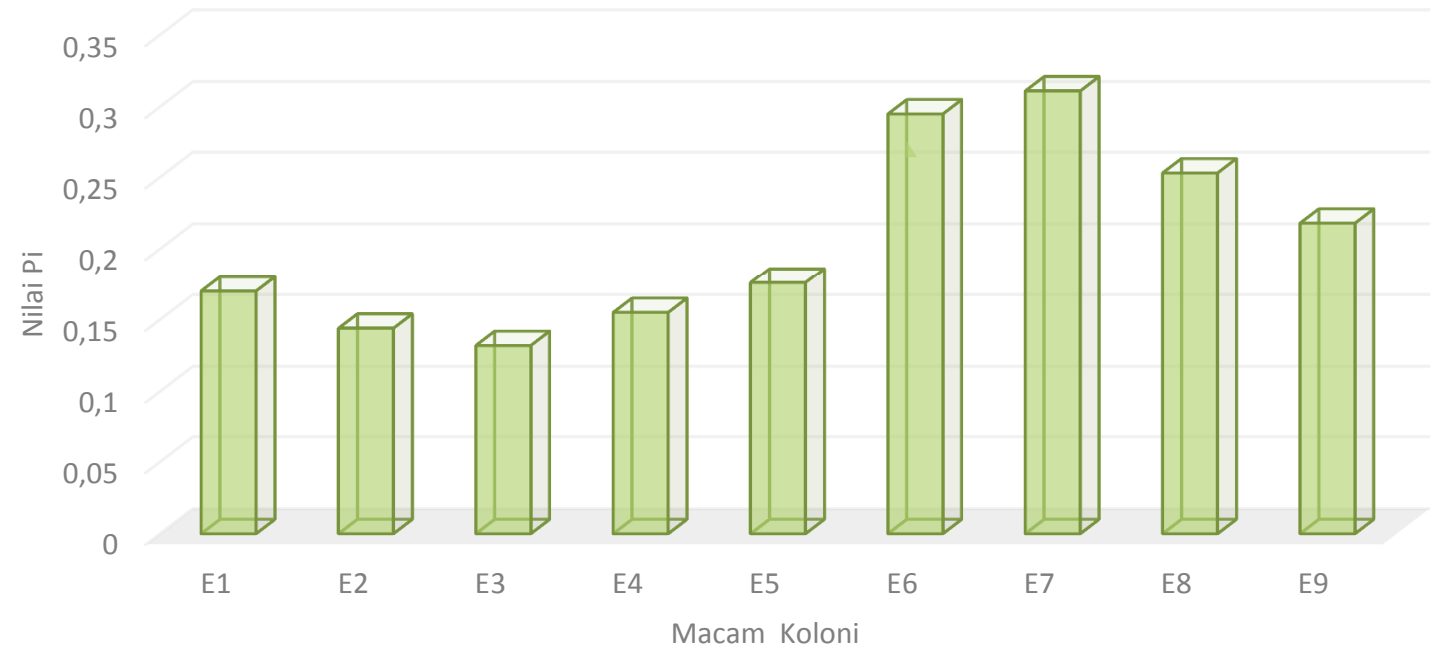

Gambar 1: indeks keanekaragaman bakteri endofit

Perlakuan pada jenis gram ini yaitu untuk menentukan sifat gram terhadap bakteri yang diamati. Nilai keanekaragaman dari yang terendah dan tertinggi diatas adalah hasil dari komonitas mikroorganisme bakteri endofit pada tanaman jeruk keprok varietas Madura. Hasil yang diperoleh dari kenekaragaman mikroorganisme terendah dapat dipengaruhi oleh gangguan musiman atau periodic oleh manusia dan alam (Gasango, dkk 2014) [9]. Nilai indeks keragaman adalah sebesar $2,16 \%$ sehingga menandakan bahwa keanekaragaman bakteri endofit tanaman jeruk keprok varietas madura termasuk dalam kategori sedang $\left(1,0<\mathrm{H}^{\prime}<3,322\right)$ yang menunjukkan bahwa produktivitas cukup, kondisi ekosistem cukup seimbang, tekanan ekologis sedang.

Pengamatan pada macam koloni bakteri di jenis gram bakteri jeruk keprok varietas Madura didapat terdapat dua gram positif dan delapan jenis gram negatif, dua gram positif yaitu dari $\mathrm{E}$ (1) 3,2 $\times 10^{7}$ dan E (5) $3,4 \times 10^{7}$. Sedangkan pada kedelan gram negatif tersebut yaitu E (2) $2,5 \times 10^{7}, \mathrm{E}(3)$ $2,2 \times 10^{7}, \mathrm{E}(4) 2,8 \times 10^{7}, \mathrm{E}(6) 8,6 \times 10^{7}, \mathrm{E}(7) 9,7 \times 7^{6}, \mathrm{E}(8) 6,3 \times 10^{7}$ dan E (9) $4,8 \times 10^{7}$. Perlakuan pada jenis gram ini yaitu untuk menentukan sifat gram terhadap bakteri yang diamati. Hasil dari jenis gram bakteri akan di paparkan pada data pengamatan koloni, populasi dan jenis gram bakteri daun ditunjukkan pada Tabel 1.

Uji antagonis dilakukan untuk mengetahui sejauh mana ke mampuan bakteri endofit melawan terhadap penyakit yang ada pada tumbuhan. Pengamatan ini dilakuka mendapatkan hasil bakteri endofit dalam menghambat jamur patogen Diplodia sp. Yang menggunakan media Plate Count Agar (PCA), Mekanisme penghambatan terjadi secara ada yang antibiosis dengan terlihat adanya zona penghambatan pertumbuhan, dan juga ada yang melakukan pertumbuhan bakteri membesar. 
Tabel 1. Data pengamatan pengamatan koloni, populasi dan jenis gram bakteri daun

\begin{tabular}{ccc}
\hline Macam koloni & Jumlah tiap gram tanah & Jenis gram (+/-) \\
\hline E 1 & $3,2 \times 10^{7}$ & Warna ungu (+) \\
E 2 & $2,5 \times 10^{7}$ & Warna merah (-) \\
E 3 & $2,2 \times 10^{7}$ & Warna merah (-) \\
E 4 & $2,8 \times 10^{7}$ & Warna merah (-) \\
E 5 & $3,4 \times 10^{7}$ & Warna ungu (+) \\
E 6 & $8,6 \times 10^{7}$ & Warna merah (-) \\
E 7 & $9,7 \times 10^{7}$ & Warna merah (-) \\
E 8 & $6,3 \times 10^{7}$ & Warna merah (-) \\
E 9 & $4,8 \times 10^{7}$ & Warna merah (-) \\
\hline
\end{tabular}

\section{Chart Title}

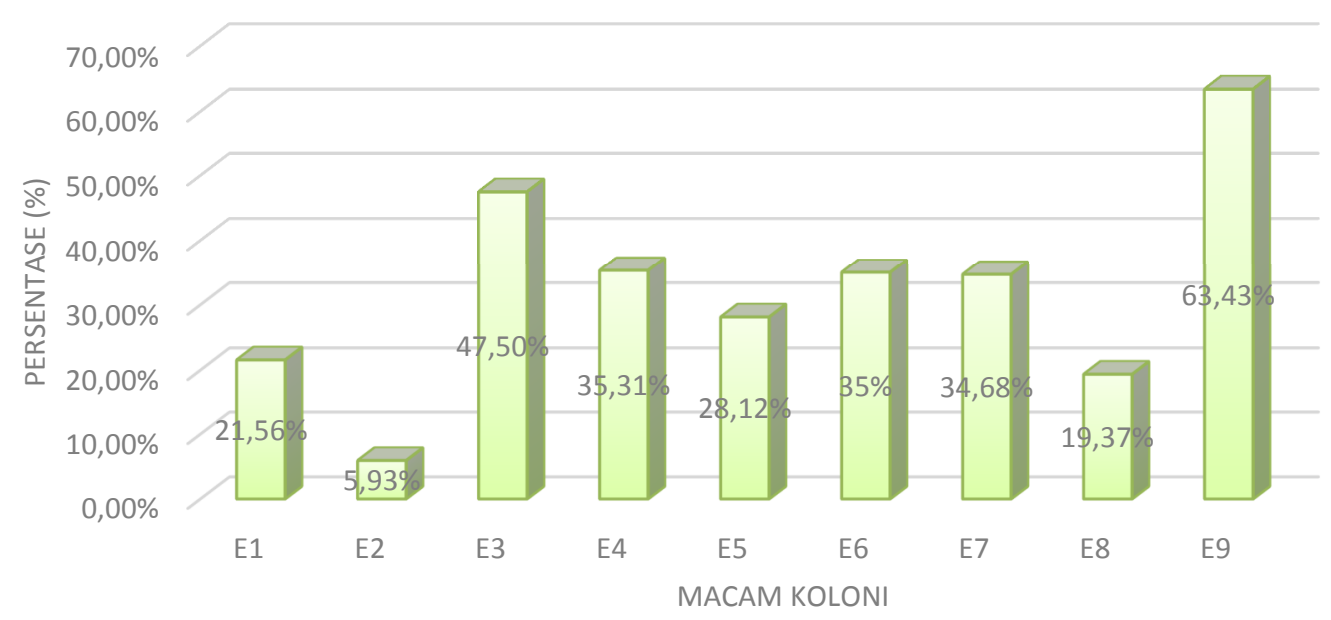

Gambar 2: Uji antagonis bakteri endofit terhadap jamur Diplodia sp.

Hasil yang bakteri endofit, maka diperoleh 4 didapat dua ulangan dari lima perlakuan, dua media dari isolate awal yaitu yang berpotensi ada 4 yaitu pada Diplodia sp. + E3 dengan persentase 47,5\%, Diplodia sp. + E4 dengan persentase 35,31\%, Diplodia sp. + E6 dengan persentase 35\% dan yang terakhir yaitu sangan berpotesi terhadap pengendaliyan penyakit yaitu Diplodia sp. + E9. dengan persentase $63,43 \%$. Beberapa bakteri endofit dilaporkan dapat berperan sebagai agen hayati yang berasosiasi dengan tanaman inangnya (Long et al., 2008) [10]. Dalam penelitian ini isolat bakteri endofit yang terpilih menunjukan reaksi antibiosis terhadap Erwinia sp. Mekanisme antibiosis berkaitan erat dengan kemampuan isolat bakteri endofit menghasilkan enzim seperti kitinase, protease, dan selulase maupun senyawa sekunder lainnya yang sangat berperan dalam menginduksi ketahanan tanaman. 


\section{Kesimpulan}

Bakteri endofit yang diisolasi dari daun jeruk keprok varietas Madura yaitu ada 9 macam koloni bakteri dan di karakteristikkan dengan media PCA, NA dan MCA Nilai indeks keragaman adalah sebesar 2,06 sehingga menandakan bahwa keanekaragaman bakteri endofit termasuk dalam kategori sedang $\left(1,0<\mathrm{H}^{\top}<3,322\right)$ bakteri endofit dalam daun.

Setelah dilakukannya uji antagonis sifat dari koloni bakteri dengan jamur Diplodia sp ada empat macam koloni bakteri endofit yang bersifat antagonis yaitu E3 persentase (47,5\%) dengan warna koloni putih susu, berbentuk bulat jenis gram (-). E4 persentase $(35,31 \%)$ dengan warna koloni putih susu, berbentuk bulat, jenis gram (-). E7 persentase $(34,68 \%)$ dengan warna koloni putih, berbentuk bulat, jenis gram (-). Dan yang terakhir yaitu dari E9 persentase $(63,43 \%)$ dengan warna koloni putih bening, berbentuk bulat, jenis gram (-).

\section{Daftar Pustaka}

[1] Petrini, O. 1991. Fungal endophytes of tree laeves. in Andew, J. and S. Hirano (eds.). Microbial Ecology of Leaves. Springer-Verlag. New York.

[2] Melliawti, R. 2006. Pengkajian Bakteri Endofit Penghasil senyawa Bioaktif untuk Proteksi Tanaman. Jurnal Biodiversitas, volume 7, Nomor 3. Halaman: 221-224. ISSN: 1412$033 X$.

[3] Hallman, J, A. Quadt-Hallmann, W.F Mahaffee, dan J.W. Kloepper. 1997. Bacterial Endophytes in Agricultural Crops. Can. J. Microbiol. 43:895-914

[4] Puspita, D., Sulistyowati, L., dan Djauhari, S. 2013. Eksplorasi Jamur Endofit Pada Tanaman Jeruk (Citrus sp.) Fusiprotoplas Dengan Ketahanan Berbeda Terhadap Botriodiplodia theobromae pat. Jurnal HPT. Volume 1 Nomor 3 September 2013.

[5] Adler, L. S., R. Karban., dan S. Y Strauss. 2001. Direct and indirect effects of alkaloids on plant fitness via herbivory and pollination. The Ecological Society of America. 82 (7): 20322044.

[6] Puspita, D., Sulistyowati, L., dan Djauhari, S. 2013. Eksplorasi Jamur Endofit Pada Tanaman Jeruk (Citrus sp.) Fusiprotoplas Dengan Ketahanan Berbeda Terhadap Botriodiplodia theobromae pat. Jurnal HPT. Volume 1 Nomor 3 September 2013.

[7] Soelarso, BR, 1996, Budidaya Jeruk Bebas Penyakit, Kanisius, Yogyakarta

[8] Syauqi, A. 2017. Mikrobiologi Lingkungan Peranan Mikroorganisme dalam Kehidupan. ANDIUnisma. Yogyakarta.

[9] Gasango, H. Manu, G. D. dan Tamarampo, J. FWS. 2104. Struktur Komunitas teripang (Holothuroidea) di pantai Desa Kakara Pulau Kecamatan Tobelo Kabupaten Tobelo. Jurnal Ilmiah Patax. Vol. 1 (4). ISSN 2302:3589

[10] Long, Hoang Hoa., Schmidt, Domnik D., Baldwin, Ian T. 2008. Native Bacterial Endophytes Promote Host Growth in a Species-Specific Manner; Phytohormone Manipulations Do Not Result in Common Growth Response. Akses 05 Januari 2019. URL:http://www.plosone.org/article/info:doi/10.1371/journal.po ne.0002702. 